$\underline{\text { www.degruyter.com/view/j/arls }}$

DOI: 10.2478/arls-2020-0012

Review Article

\title{
Rosehip (Rosa canina) as a Beneficial Dietary Feed in Poultry Nutrition: Review
}

\author{
Alexandru P. Vlaicu*, Raluca P. Turcu, Dumitra T. Panaite \\ Department of Chemistry and Animal Nutrition Physiology, National Research - Development Institute for \\ Animal Biology and Nutrition, Calea Bucharest no. 1, Balotești, Romania
}

Received March, 2020; Revised May, 2020, Accepted June, 2020

\begin{abstract}
Today the aromatic and medicinal plants have gained more recognition as dietary supplements because they are characterized as natural, safe, eco-friendly, and possess many health-promoting properties, making their ongoing usage part of an emerging field at the cutting edge of science. Rosehip (Rosa canina), a medicinal plant, is widely known as a valuable source of various nutrients and biologically active substances, mostly polyphenols and vitamin $C$. The chemical composition differs depending on the climate, growing region, cultivation practice, maturity, soil type, harvesting and storage conditions. Over the years, significant variations in vitamins (106-967 mg/ $100 \mathrm{~g})$, minerals (Fe 59.40-72.90 ppm; Zn 3.69-4.51 ppm; Ca 133.30-146.70 ppm), essential fatty acids (33.8\% - 49.7\% a-linolenic), phenols (9982 GAE - mg/100 g), antioxidants (lutein, zeaxanthin) among other bioactive components and nutrients have been reported by various researchers. Both in vivo and in vitro studies have shown that rosehip used at an appropriate dose in broilers and laying hens dietary feed could have some beneficial effects.
\end{abstract}

Key words: rosehip effects; chemical composition; feed supplement; poultry.

\section{Introduction}

After 1998s, when the use of drugs, especially antibiotics, as additives in animal feed, started to phase out, and completely banned in 2006 by the European Union, due to cross-resistance against pathogens and residues in tissues [1], researchers have searched for new methods and alternatives to antibiotics as natural additives to improve the growth rate and productive performances of poultry. In this view, finding new sources of natural additives, it is very important, due to consumers demand for healthier foods, which provide health benefits and help in food preservation [2]. Natural sources of compounds with antioxidant potential (fruits, vegetables, herbs) can be used as ingredients with phytogenic action against a number of degenerative diseases

\footnotetext{
* Corresponding author: Alexandru P. Vlaicu, alexandru.vlaicu@outlook.com

(cc) BY-NC-ND (c2020 A. P. Vlaicu et al., published by De Gruyter Open. This work was licensed under the Creative Commons Attribution-NonCommercialNoDerivs 3.0 License
}

caused partly by oxidative stress [3]. In the last decades, rosehip plants have been studied more and more due to their very important therapeutic properties and biologically active compounds [4]. Rosehip (Rosa canina) is one of the most popular medicinal plants, recognized for its therapeutic properties. Studies conducted over time have highlighted the medicinal properties of rosehip in both human and animal treatment [5]. The physiological properties of rosehip are mainly attributed to the high content of phenols and the broad spectrum of biochemical activities, such as antioxidant, antimutagenic, anticarcinogenic $[6,7]$. The main component of rosehip, responsible for their antioxidant activity, is ascorbic acid (vitamin C), which is accumulated in the fruit pulp. Besides the ascorbic acid, rosehip contain a wide range of vitamins, organic acids, flavonoids, carotenoids, fatty acids, essential oils and other biologically active substances (such as: tannins, pectin, nitrous compounds, sugars, fats). Also, rosehip contain significantly important minerals $(\mathrm{Na}, \mathrm{K}$, $\mathrm{Ca}, \mathrm{P}, \mathrm{Mn}, \mathrm{Mg}, \mathrm{Fe}$ ) that activate about 200 
enzymes in the body $[8,9]$. These compounds play an important role in maintaining fruit quality and determining nutritional value [10]. In this context, rosehip and its derivatives have shown promising results in experiments carried out on poultry [1114].

\section{Chemical composition of rosehip}

Analytical studies have unveiled the presence of several nutrients in rosehips. Vitamin $\mathrm{C}$ is the most abundant vitamin from the rosehip fruit. Dried fruits can accumulate between 1000 to 4000 $\mathrm{mg}$ per $\mathrm{dL}$ ascorbic acid [15]. This concentration is higher than those found in vegetables and 10 times higher than that of lemons and black currants [16]. Vitamin C concentration significantly $(P<0.05)$ varies between different rosehip species (106-2712 mg per 100g) [17-20]. Others [21] reported that the amount of Vitamin $\mathrm{C}$ from rosehip ranged from $629-967 \mathrm{mg}$ per $100 \mathrm{~g}$. The antioxidant properties are also given by their carotenoid content [22], in particular, $\beta$-carotene (approx. $1.3 \mathrm{mg}$ per $100 \mathrm{~g} \mathrm{DM}$ ) and lycopene, which act either as pro-vitamin A or as chains of antioxidants that protect cells and organisms against photo-oxidation [23]. The role of lycopene in the prevention of chronic diseases has been evaluated both in epidemiological studies, as well as in animal studies and human clinical studies [22]. Rosehips are also a valuable source of anthocyanin $(0.38 \mathrm{mg}$ per $100 \mathrm{~g}$ ), being the ones that give fruit colour and antioxidant activity. According to [24] the most important anthocyanin in the rosehip is cyanidin-3-O-glucoside. Rosehip was found to have a high total polyphenol content (145.7 mg per $100 \mathrm{~g}$ ) [25], which exhibit a wide range of biological effects including antibacterial, anti-inflammatory, antiallergic, hepatoprotective, antithrombotic, antiviral, anticarcinogenic and vasodilator actions [26]. These biological functions have been attributed to exfoliation of free radicals and antioxidant activity. The flavonoid content of rosehip ranged from 8.68 to $34.99 \mathrm{mg}$ per $\mathrm{g}$ extract [27] and have shown to be highly effective in eliminating most types of oxidizing molecules, including single oxygen and various free radicals, which are involved in DNA damage and tumour promotion [28].

Also, rosehip is a rich source of minerals, both micro and macro elements which have an important role in the absorption of $\mathrm{Fe}$ in the body and the biosynthesis of collagen [29]. The mineral content from rosehip reported in literature have a wide range of results as follows: $\mathrm{Na}$ (3.97 to 4.67 $\mathrm{mg} / \mathrm{kg}$ ); K (890.50 to $1023.90 \mathrm{mg} / \mathrm{kg}$ ); P (1850 to $2200 \mathrm{mg} / \mathrm{kg}$ ); Fe (59.40 to $72.90 \mathrm{ppm}$ ); Zn (3.69 to $4.51 \mathrm{ppm}$ ); $\mathrm{Mn}$ (22.40 to $44.80 \mathrm{ppm}) ; \mathrm{Mg}$ (162.70 to 183.90$)$ and $\mathrm{Ca}$ (133.30 to $146.70 \mathrm{ppm}$ ) [30,
31]. It is noteworthy that in terms of mineral content $(\mathrm{P}, \mathrm{Ca}, \mathrm{Mg}$ and $\mathrm{Na})$, rosehip have a much higher content compared with other small fruits, such as strawberry, red blueberry, black blueberry, raspberries, blueberries and blackberries [32].

Regarding the fatty acids, rosehip is known to have saturated and unsaturated fatty acids in composition which act as inhibitors of COX-1 and 2 formations [33]. The literature has shown that rosehip contains mostly palmitic, linoleic and $\alpha$ linolenic acid as the main fatty acids present in lipophilic extracts from rosehips, along with low amounts of stearic acid and oleic acid. Significant differences have been reported especially for palmitic acid $(16.4 \%$ to $26.6 \%)$ and a-linolenic acid $(33.8 \%$ to $49.7 \%)$, according to [34]. This differences in the composition of fatty acids are related to environmental conditions (climate, altitude, etc.), which are known to have an impact on the composition of fatty acids. Rosehip seeds have a higher level of linolenic acid than canola and soybean vegetable oils, the main alimentary sources of linolenic acid [35]. High levels of linoleic and linolenic acid in rosehip seed can make it susceptible to lipid oxidation, but its antioxidant content may contribute to oxidative stability [36]. Linolenic acid has a protective effect against heart disease and is important in brain and retinal development. Both, linoleic and linolenic acids (essential fatty acids) are the precursors of omega- 3 and omega- 6 fatty acids. A balanced intake of omega- 3 and omega- 6 fatty acids is important in the prevention of chronic diseases such as coronary heart disease and cancer. The higher percentage of polyunsaturated fatty acids and the ratio of linolenic to linoleic acid can make rosehip a valuable source for omega fatty acids [37].

\section{Effects of rosehip on poultry diets}

The addition of natural plants and their derivatives to livestock nutrition is an interesting tool for providing supplements with biologically active compounds. These reveal considerable properties such as antimicrobial, antiviral, antifungals, antioxidant, anti-inflammatory, and immunostimulatory [38]. Moreover, the use of natural plants due to their valuable compounds is fundamental for successful development of novel, healthy foods, nowadays known as functional foods, which, beyond their nutritional effects have demonstrated benefits to both human and animal organism by improving the state of health or wellbeing [39]. Regarding the rosehip supplement as feed additive in broiler diets, some authors [40] showed that average daily gain (ADG) and broiler carcasses were heavier $(1.71 \mathrm{~kg})$ compared with 
rosemary $(1.54 \mathrm{~kg}$ ), when $25 \mathrm{~g} / \mathrm{kg}$ rosehip or rosemary supplement was added, but at the same time, had the highest average daily feed intake (ADFI) (g/chick) and feed conversion ratio (FCR) (g feed/g of ADG) when compared with rosemary or chokeberry as natural feed additives. Same authors stated that during storage (9 days), TBARS of breast meat increased $(P<0.05)$ when rosehip was compared with vitamin $\mathrm{E}$ supplement, which showed the antioxidant potential of rosehip. This effect could be easily obtained by using herbal supplements which exert antioxidant properties not only in the feed but also transfer the active principles to the meat. Tekeli [11] obtained the highest live weight of broilers supplemented with 10 and $20 \mathrm{~g} / \mathrm{kg}$ rosehip under stress conditions, but when the dose of rosehip (30 g/kg) was increased, he observed a significantly decreased in live body weight $(P<0.01)$. Loetscher, [40] tested the effect of four natural antioxidants derived from plants as feed additives for broilers and laying hens and their impact on the oxidative stability of final products (meat and eggs). The results showed that $25 \mathrm{~g} / \mathrm{kg}$ feed of rosehip significantly slowed the lipid oxidation in broiler meat. Similar, [11] obtained positive effects on meat quality of chickens by investigating the rosehip fruits as natural sources of carotene and vitamin C. Regarding the effect of rosehip in layers diets there are few published data. Vlaicu [12] found that $1.5 \%$ and $3 \%$ rosehip powder negatively affected the FCR due to high crude fiber content, but improved the egg weight. Similar results were obtained by [13] who reported significant differences $(P<0.05)$ regarding the layer performances. Also, they stated that the antioxidant effect of dietary rosehip did not influenced the total cholesterol, cholesterol esters, free fatty acids and triglyceride contents in the egg yolks. The antioxidant effect of rosehip in poultry diets is very important in order to delay or inhibit the oxidation of other substances by inhibiting the initiation or propagation of oxidative chain reactions [41]. Natural antioxidants can protect biologically important cellular components from oxidative processes caused by reactive oxygen species. Meat and egg quality can be improved by incorporating natural antioxidants into animal diets. Slowing down the lipid oxidation process and increasing antimicrobial activity are some positive effects of natural antioxidants on meat quality parameters [42,43]. However, rosehip and its by-products, require much more detailed research.

Another beneficial effect of rosehip when use in poultry diet is his antibacterial potential especially against certain microorganisms and strains of Staphylococcus aureus, which is prominent for their high level of resistance to antibiotics due to their encoded efflux mechanism, Escherichia coli, Klebsiella pneumoniae and Acinetobacter spp. [44]. Pathogens such as Clostridium perfringens and Escherichia coli usually attract more attention, due to the fact that these microorganisms are responsible for serious poultry diseases. The phytochemical constituents present in rosehip, such as ascorbic acid, tocopherols, tannins, pectin, minerals, fatty acids, carotenoids and phenolic compounds aid its microbial effects [45]. The antibacterial activity of the rosehip oil has been reported by [46]. It had a significant activity $(P \leq 0.05)$ in maintaining the intestinal health of broiler chicks. Supported by promising results, the use of rosehip as phytogenic feed additives has recently been proposed as an alternative to antibiotics to control oxidative stress in broiler chicks. Regarding the health effect of rosehip [14] reported that rosehip fruits, used in the diet of broiler chickens had beneficial effects on some biochemical properties in the blood. The authors that serum urea, creatinine, uric acid, triglyceride, total protein, glucose, $\mathrm{K}$ and $\mathrm{Cl}$ were not affected by the use of rosehip, and cholesterol levels decreased due to the high content of cellulose and flavonoids. Contrary, [11] reported that there were no significant differences in uric acid, total protein, globulin, HDL and LDL, but the concentrations of albumin, ALT, cholesterol, triglycerides, VLDL and $\mathrm{Ca}$ increased by $15 \%$ compared to the control group in an experiment on laying hens. Nurulhuda [47] reported that some phenolic compounds present in rosehip, such as flavonoids, anthocyanidins and anthocyanins, can reduce endogenous cholesterol uptake and synthesis. Also, it was highlighted that rosehip can have hypo-cholesterolemic activity, due to their rich phenolic compounds.

\section{Conclusions}

This review has focused on the beneficial effects of dietary rosehip (Rosa canina) including fatty acids, phenolic compounds and mineral content. Rosehip components may act as antioxidants, anti-inflammatory, antimicrobial, anti-tumour and decrease the cholesterol level from plasma. Studies on the application of rosehip in broiler production showed positive effects on growth performances, health status, production parameters, and meat quality. Additional studies are required regarding the use of rosehip in layers diet as dietary feed ingredient. Based on the presented results, rosehip is considered to be a potential novel plant-derived growth promoter and its use warrants further investigation. In addition, the potential for the application of rosehip as a 
growth promoter certainly deserves further attention.

\section{Acknowledgements}

This work was supported by a grant of the Romanian National Authority for Scientific Research and Innovation, CNCS/CCCDI - UEFISCDI, project number 8PCCDI/2018 PC3, within PN-III-P1-1.2-PCCDI-2017 and by Program 1. Development National ResearchDevelopment, Subprogram 1.2. Institutional Performance-Projects funding excellence in R\&D, Contract no.17 PFE"

\section{References}

1. Florou-Paneri, P., Christaki, E. \& Giannenas, I. (Eds.). (2019). Feed Additives: Aromatic Plants and Herbs in Animal Nutrition and Health. Academic Press. 2. Jiménez, S., Jiménez-Moreno, N., Luquin, A., Laguna, M., Rodríguez Yoldi, M. J. \& AncínAzpilicueta, C. (2017). Chemical composition of rosehips from different Rosa species: an alternative source of antioxidants for the food industry. Food Additives \& Contaminants: Part A, 34(7): 1121-1130. https://doi.org/10.1080/19440049.2017.1319071

3. Halvorsen, B. L., Holte, K., Myhrstad, M. C., Barikmo, I., Hvattum, E., Remberg, S. F. \& Moskaug, Ø. (2002). A systematic screening of total antioxidants in dietary plants. The Journal of nutrition, 132(3), 461471. https://doi.org/10.1093/jn/132.3.461

4. Al-Yafeai, A., Malarski, A. \& Böhm, V. (2018). Characterization of carotenoids and vitamin E in Rosa rugosa and Rosa canina: Comparative analysis. Food chemistry, 242: $435-442$.

https://doi.org/10.1016/j.foodchem.2017.09.070

5. Tumbas, V. T., Čanadanović-Brunet, J. M. Četojević-Simin, D. D., Ćetković, G. S., Đilas, S. M. \& Gille, L. (2012). Effect of rosehip (Rosa canina L.) phytochemicals on stable free radicals and human cancer cells. Journal of the Science of Food and Agriculture, 92(6):

https://doi.org/10.1002/isfa.4695

6. Nakamura, Y., Watanabe, S., Miyake, N., Kohno, H. \& Osawa, T. (2003). Dihydrochalcones: evaluation as novel radical scavenging antioxidants. Journal Agriculture Food Chemistry, 51: 3309-3312. https://doi.org/10.1021/jf0341060

7. Vlaicu, P. A., Panaite, T. D., Voicu, I., Turcu, R. P., Olteanu, M. \& Ropota, M. (2018). Determining the feeding value of some food industry byproducts. Scientific Papers: Animal Science and Biotechnologies, 51(1), 62-69.

8. Ulchenko N., Bckkcr, N., Aripov, O. \& Glushcnkova, A. (1995) Lipids of Rosa canina pericarp. Chemistry of Natural Compounds, 45 (6), 867868.

9. Jakubcová, Z., Horky, P., Dostalova, L., Sochor, J., Tomaskova, L., Baron, M. \& Zeman, L. (2015). Study of antioxidant and antimicrobial properties of grapevine seeds, grape and rosehip pressing. Potravinarstvo Slovak Journal of Food Sciences, 9(1), 382-387. https://doi.org/10.5219/503

10. Vlaicu, P. A., Panaite, T. D., Tabuc, C., Soica, C. \& Stanel, I. (2019). Effect of a blend of commercial oils on growth performance and intestinal microflora population in broiler chickens. Scientific Papers, Series D. Animal Science, 62(1), 130-137.

11. Tekeli, A. (2014). Effect of rosehip fruit (Rosa canina L.) supplementation to rations of broilers grown under cold stress conditions on some performance, blood, morphological, carcass and meat quality characteristics. European Poultry Science, 78. https://doi.org/10.1399/eps.2014.19

12. Vlaicu, P. A., Dragotoiu, D., Panaite, T. D., Untea, A., Saracila, M. \& Mitoiu, M. (2017). Effect of rosehip addition to $\Omega 3$ PUFA-high layer diets on hen performance and egg quality. In Proceedings of the 21st European Symposium on Poultry Nutrition, Salou, Spain, pp.220.

13. Kaya, H., Kaya, A., Esenbuğa, N. \& Macit, M. (2019). The effect of rosehip seed supplementation into laying hens diets on performance, egg quality traits, yolk lipid profile and serum parameters. Alınteri Zirai Bilimler Dergisi, 34(1): 84-87.

14. Gheorghe, A., Vlaicu, P.A., Olteanu, M., Visinescu, P. \& Criste, R.D. (2019). Obtaining eggs enriched in polyunsaturated fatty acids (PUFA). 1. Use of vegetable sources rich in PUFA as functional ingredients in layer hens diets: A review. Archiva Zootechnica 22:2, 54-85.

15. Kharazmi, A. (2008) Laboratory and preclinical studies on the anti- inflammatory and antioxidant properties of rosehip powder-Identification and characterization of the active component. Osteoarthritis and Cartilage, 16:5-7. https://doi.org/10.1016/S10634584(08)60003-5

16. Soner, K., Baydar, H. \& Erb, S. (2009). Variations in Chemical Compositions of Rosa damascena mill and Rosa canina L. fruits. Czech Journal of Food Science, 27(3):178-184. https://doi.org/10.17221/5/2009-CJFS

17. Gunes, M. \& Sen, S. M. (2001). A study on improvement of wild rose hips (Rosa sp.) growing in Tokat province by selection. Horticulture, 30, 9-16.

18. Ercisli, S. (2007). Chemical composition of fruits in some rose (Rosa spp.) species. Food chemistry, 104 (4):

https://doi.org/10.1016/j.foodchem.2007.01.053

19. Yörük, İ., Türker, M., Kazankaya, A., Erez, M., Battal, P. \& Celik, F. (2008). Fatty acid, sugar and vitamin contents in rose hip species. Asian Journal of Chemistry, 20: 1357-1364.

20. Kazaz, S., BaydaR, H. \& ERBaS, S. (2009). Variations in chemical compositions of Rosa damascena Mill. and Rosa canina L. fruits. Czech Journal of Food Sciences, 27(3), 178-184. https://doi.org/10.17221/5/2009-CJFS

21. Nojavan, S., Khalilian, F., Kiaie, F. M., Rahimi, A., Arabanian, A. \& Chalavi, S. (2008). Extraction and quantitative determination of ascorbic acid during different maturity stages of Rosa canina L. fruit. Journal of food composition and analysis, 21(4), 300-305. https://doi.org/10.1016/j.jfca.2007.11.007

22. Rao, A.V. \& Rao, L.G. (2007). Carotenoids and human health. Pharmacology Research, 55: 207-216. https://doi.org/10.1016/j.phrs.2007.01.012

23. Ghazghazi, H., Miguel, M. G., Hasnaoui, B., Sebei, H., Ksontini, M., Figueiredo, A. C. \& Barroso, J. G. (2010). Phenols, essential oils and carotenoids of 
Rosa canina from Tunisia and their antioxidant activities. African Journal of Biotechnology, 9(18), 27092716.

24. Guimarães, R., Barros, L., Dueñas, M., Carvalho, A. M., Queiroz, M. J. R., Santos-Buelga, C. \& Ferreira, I. C. (2013). Characterisation of phenolic compounds in wild fruits from Northeastern Portugal. Food Chemistry, 141(4), 3721-3730. https://doi.org/10.1016/j.foodchem.2013.06.071

25. Guerrero, J., Ciampi, L., Castilla, A., Medel, F., Schalchli, H., Hormazabal, E. \& Alberdi, M. (2010). Antioxidant capacity, anthocyanins, and total phenols of wild and cultivated berries in Chile. Chilean Journal of Agricultural Research, 70(4), 537-544.

26. Soobrattee, M. A., Neergheen, V. S., LuximonRamma, A., Aruoma, O. I. \& Bahorun, T. (2005). Phenolics as potential antioxidant therapeutic agents: mechanism and actions. Mutation Research/Fundamental and Molecular Mechanisms of Mutagenesis, 579(1-2), 200-213.

27. Barros, L., Carvalho, A. M., Morais, J. S. \& Ferreira, I. C. (2010). Strawberry-tree, blackthorn and rose fruits: Detailed characterisation in nutrients and phytochemicals with antioxidant properties. Food chemistry, 120(1), 247-254. https://doi.org/10.1016/j.foodchem.2009.10.016

28. Marchand, L.L. (2002) Cancer preventive effects of flavonoids-A review. Biomedicine and Pharmacotherapy, 56: 296-301. https://doi.org/10.1016/S0753-3322(02)00186-5

29. Chrubasik, C., Duke, R. K. \& Chrubasik, S. (2006). The evidence for clinical efficacy of rose hip and seed: a systematic review. Phytotherapy Research: An International Journal Devoted to Pharmacological and Toxicological Evaluation of Natural Product Derivatives, 20(1), 1-3. https://doi.org/10.1002/ptr.1729

30. Szentmihályi, K., Vinkler, P., Lakatos, B., Illés, V. \& Then, M. (2002). Rose hip (Rosa canina L.) oil obtained from waste hip seeds by different extraction methods. Bioresource technology, 82(2), 195-201.

31. Demir, F. \& Özcan, M. (2001). Chemical and technological properties of rose (Rosa canina L.) fruits grown wild in Turkey. Journal of food engineering, 47(4), 333-336.

32. Veberic, R., Slatnar, A., Bizjak, J., Stampar, F. \& Mikulic-Petkovsek, M. (2015). Anthocyanin composition of different wild and cultivated berry species. LWT-Food Science and Technology, 60(1), 509-517. https://doi.org/10.1016/j.Iwt.2014.08.033

33. Reininger, E. A. \& Bauer, R. (2006). Prostaglandin- $\mathrm{H}$-synthase (PGHS)-1 and-2 microtiter assays for the testing of herbal drugs and in vitro inhibition of PGHS-isoenzyms by polyunsaturated fatty acids from Platycodi radix. Phytomedicine, 13(3), 164169. https://doi.org/10.1016/j.phymed.2005.03.006 34. Ercisli, S. (2007). Chemical composition of fruits in some rose (Rosa spp.) species. Food chemistry, 104(4), https://doi.org/10.1016/j.foodchem.2007.01.053

35. Pardo, J. E., Fernández, E., Rubio, M., Alvarruiz, A. \& Alonso, G. L. (2009). Characterization of grape seed oil from different grape varieties (Vitis vinifera). European journal of lipid science and technology, 111(2), 188-193. https://doi.org/10.1002/ejlt.200800052

36. Jing, P. U., Ye, T., Shi, H., Sheng, Y., Slavin, M., Gao, B. \& Yu, L. L. (2012). Antioxidant properties and phytochemical composition of China-grown pomegranate seeds. Food Chemistry, 132(3), 14571464. https://doi.org/10.1016/j.foodchem.2011.12.002 37. Yehuda, S. (2003). Omega-6/Omega-3 ratio and brain-related functions. World Review of Nutrition and Dietetics, 92: 37-56. https://doi.org/10.1159/000073791 38. Diaz-Sanchez, S., D'Souza, D., Biswas, D. \& Hanning, I. (2015). Botanical alternatives to antibiotics for use in organic poultry production. Poultry science, 94(6), 1419-1430. https://doi.org/10.3382/ps/pev014 39. Ismail, M. \& Imam, M. U. (2014). Plant bioresources and their nutrigenomic implications on health. Novel Plant Bioresources: Applications in Food, Medicine and Cosmetics, 383-394. https://doi.org/10.1002/9781118460566.ch27 40. Loetscher, Y., Kreuzer, M. \& Messikommer, R. E. (2013). Oxidative stability of the meat of broilers supplemented with rosemary leaves, rosehip fruits, chokeberry pomace, and entire nettle, and effects on performance and meat quality. Poultry science, 92(11), 2938-2948. https://doi.org/10.3382/ps.2013-03258

41. Velioglu, Y. S., Mazza, G., Gao, L. \& Oomah, B. D. (1998). Antioxidant activity and total phenolics in selected fruits, vegetables, and grain products. Journal of agricultural and food chemistry, 46(10), 4113-4117. https://doi.org/10.1021/jf9801973

42. Fasseas, M. K., Mountzouris, K. C., Tarantilis, P. A., Polissiou, M. \& Zervas, G. (2008). Antioxidant activity in meat treated with oregano and sage essential oils. Food Chemistry, 106(3), 1188-1194.

43. Vlaicu, P. A., Panaite, T. D., Olteanu, M., Turcu, R. P., Saracila, M. \& Criste, R. D. (2018). Effect of the dietary oregano (Origanum vulgare L.) powder and oil on the performance, carcass and organs development of broilers reared under heat stress (32 C). Scientific Papers-Animal Science Series: Lucrări Ştiinţifice - Seria Zootehnie, 69, 207-213.

44. Horváth, G., Molnár, P., Radó-Turcsi, E., Deli, J., Kawase, M., Satoh, K. \& Molnár, J. (2012). Carotenoid composition and in vitro pharmacological activity of rose hips. Acta Biochimica Polonica, 59(1). 45. Yilmaz, S. O. \& Ercisli, S. E. Z. A. I. (2011). Antibacterial and antioxidant activity of fruits of some rose species from Turkey. Romanian Biotechnological Letter, 16(4), 6407-6411.

46. Vlaicu, P. A., Saracila, M., Panaite, T. D., Tabuc, C., Bobe, E. \& Criste, R. D. (2017). Effect of the dietary grape seeds and rosehip oils given to broilers (14-42 days) reared at $32 \mathrm{C}$ on broiler performance, relative weight of carcass cuts and internal organs and balance of gut microflora. Archiva Zootechnica, 20(1), 77.

47. Nurulhuda, M. H., Azlan, A., Ismail, A., Amom, Z. \& Shakirin, F. H. (2012). Cholesterol-lowering and atherosclerosis inhibitory effect of Sibu olive in cholesterol fed-rabbit. Asian Journal of Biochemistry, 7(2), 80-89. doi:10.3923/ajb.2012.80.89 